OPEN ACCESS

Edited by:

Zhenhai Chen

Yangzhou University, China

Reviewed by:

Irit Davidson,

Kimron Veterinary Institute, Israel Joachim Denner,

Robert Koch Institute, Germany

*Correspondence:

Joaquim Segalés

joaquim.segales@irta.cat

Specialty section:

This article was submitted to Veterinary Infectious Diseases,

a section of the journal

Frontiers in Veterinary Science

Received: 08 October 2018 Accepted: 28 November 2018 Published: 12 December 2018

Citation:

Klaumann F, Correa-Fiz F, Franzo G,

Sibila M, Núñez Jl and Segalés $J$

(2018) Current Knowledge on Porcine circovirus 3 (PCV-3): A Novel Virus

With a Yet Unknown Impact on the

Swine Industry. Front. Vet. Sci. 5:315. doi: 10.3389/fvets.2018.00315

\section{Current Knowledge on Porcine circovirus 3 (PCV-3): A Novel Virus With a Yet Unknown Impact on the Swine Industry}

\author{
Francini Klaumann 1,2, Florencia Correa-Fiz ${ }^{2}$, Giovanni Franzo ${ }^{3}$, Marina Sibila $^{2}$, \\ José I. Núñez ${ }^{2}$ and Joaquim Segalés ${ }^{4,5 *}$
}

${ }^{1}$ CAPES Foundation, Ministry of Education of Brazil, Brasilia, Brazil, ${ }^{2}$ IRTA, Centre de Recerca en Sanitat Animal (CReSA, IRTA-UAB), Campus de la Universitat Autònoma de Barcelona, Barcelona, Spain, ${ }^{3}$ Department of Animal Medicine, Production and Health (MAPS), University of Padua, Padua, Italy, ${ }^{4} \cup A B$, Centre de Recerca en Sanitat Animal (CReSA, IRTA-UAB), Campus de la Universitat Autònoma de Barcelona, Barcelona, Spain, ${ }^{5}$ Departament de Sanitat i Anatomia Animals, Facultat de Veterinària, Universitat Autònoma de Barcelona, Barcelona, Spain

Porcine circovirus 3 (PCV-3) is a recently described virus belonging to the family Circoviridae. It represents the third member of genus Circovirus able to infect swine, together with PCV-1, considered non-pathogenic, and PCV-2, one of the most economically relevant viruses for the swine worldwide industry. PCV-3 was originally found by metagenomics analyses in 2015 in tissues of pigs suffering from porcine dermatitis and nephropathy syndrome, reproductive failure, myocarditis and multisystemic inflammation. The lack of other common pathogens as potential infectious agents of these conditions prompted the suspicion that PCV-3 might etiologically be involved in disease occurrence. Subsequently, viral genome was detected in apparently healthy pigs, and retrospective studies indicated that PCV-3 was already present in pigs by early 1990s. In fact, current evidence suggests that PCV-3 is a rather widespread virus worldwide. Recently, the virus DNA has also been found in wild boar, expanding the scope of infection susceptibility among the Suidae family; also, the potential reservoir role of this species for the domestic pig has been proposed. Phylogenetic studies with available PCV-3 partial and complete sequences from around the world have revealed high nucleotide identity (>96\%), although two main groups and several subclusters have been described as well. Moreover, it has been proposed the existence of a most common ancestor dated around 50 years ago. Taking into account the economic importance and the well-known effects of PCV-2 on the swine industry, a new member of the same family like PCV-3 should not be neglected. Studies on epidemiology, pathogenesis, immunity and diagnosis are guaranteed in the next few years. Therefore, the present review will update the current knowledge and future trends of research on PCV-3.

\footnotetext{
Keywords: Porcine circovirus 3, domestic pig, wild boar, infection, epidemiology
} 


\section{INTRODUCTION}

The evolution of emerging diseases is associated with factors embedded in the concept "host-agent-environment triangle" (1). To infect the host and cause disease, the pathogen needs to evade host defenses, which may occur through single point mutations, genome rearrangements, recombination and/or translocation (2). Genetic uniformity generated through genetic selection of the host (3) and the fact that demographic changes, intensification of farming, and international commerce have occurred markedly over the last decades, must be also considered as essential factors for the development of emerging diseases (4-6).

As well as in humans, emerging diseases drastically affect animal populations, especially food-producing animals. Livestock production in large communities (i.e., pig farms or poultry flocks) represents an excellent environment to facilitate the transmission and maintenance of huge viral populations, contributing to the pathogen evolution (through mutation, recombination and reassortment, followed by natural selection) (7-9). The intensification of livestock during the last four decades has probably been one of the main factors that contributed to the emergence of new pathogens and/or pathogen variants, leading to changes in the epidemiology and presentation of diseases (10).

The number of viral infectious diseases in swine has significantly increased in the last 30 years. Several important worldwide distributed viruses have been reported in this period, including Porcine reproductive and respiratory syndrome virus (PRRSV, family Arteriviridae), Porcine circovirus 2 (PCV-2, family Circoviridae) and Porcine epidemic diarrhea virus (PEDV, family Coronaviridae). In addition to those worldwide widespread viruses, an important number of novel swine pathogens causing different types of diseases has been described $(11,12)$. Although their economic impact might be variable, they are considered significant infection agents and their monitoring is nowadays performed in some parts of the world. Among others, relevant examples are Porcine deltacoronavirus (associated with diarrhea) (12), Senecavirus A (causing a vesicular disease and increased preweaning mortality) (11), Porcine sapelovirus (found in cases of polioencephalomyelitis) (13), Porcine orthoreovirus (assumed to cause diarrhea) (14), Atypical porcine pestivirus (cause of congenital tremors type II) (15) and HKU2-related coronavirus of bat origin (associated with a fatal swine acute diarrhea syndrome) (16).

Besides overt emerging diseases of swine, many other novel infectious agents have been detected in both healthy and diseased animals, and their importance is under discussion. This group of agents is mainly represented by Torque teno sus viruses, Porcine bocavirus, Porcine torovirus and Porcine kobuvirus, which are thought to cause subclinical infections with no defined impact on production $(13,17,18)$. An exception may be represented by Hepatitis E virus (HEV); although it seems fairly innocuous for pigs, it is considered an important zoonotic agent $(19,20)$. Recently, a novel member of the Circoviridae family named Porcine circovirus 3 (PCV- 3), with unknown effects on pigs, has been discovered $(21,22)$.
Porcine circovirus 3 (PCV-3) was first described in 2015 in North Carolina (USA) in a farm that experienced increased mortality and a decrease in the conception rate (21). Sows presented clinical signs compatible with porcine dermatitis and nephropathy syndrome (PDNS) and reproductive failure. In order to identify the etiological pathogen, aborted fetuses and organs from the affected sows were collected for further analyses. Whilst histological results were consistent with PCV2 -systemic disease, both immunohistochemistry (IHC) and quantitative PCR (qPCR) methods to detect PCV-2 yielded negative results. Samples were also negative for PRRSV and Influenza A virus. Homogenized tissues from sows with PDNSlike lesions and three fetuses were tested through metagenomic analysis, revealing the presence of an uncharacterized virus (21). Further analyses using rolling circle amplification (RCA) followed by Sanger sequencing showed a circular genome of 2,000 nucleotides. Palinski et al. (21) also performed a brief retrospective study through $\mathrm{QPCR}$ on serum samples from animals clinically affected by PDNS-like lesions (but negative for PCV-2 by IHC) and pigs with porcine respiratory diseases. Results revealed PCV-3 qPCR positivity in 93.75 and $12.5 \%$ of the analyzed samples, respectively (21).

Interestingly, almost concomitantly, another research group from the USA reported a clinical picture pathologically characterized by multi-systemic and cardiac inflammation of unknown etiology in three pigs of different ages ranging between 3 and 9 week-old (22). Several tissues from these animals were tested by next-generation sequencing (NGS) methods and PCV3 genome was found. Beyond NGS, in situ hybridization was performed in one out of these three pigs, confirming PCV-3 mRNA in the myocardium (cytoplasm of myocardiocytes and inflammatory cells mainly, although to a very low frequency).

Based on these two initial works, the name PCV-3 was proposed as the third species of circoviruses affecting pigs, since pairwise analysis demonstrated significant divergence with the existing PCVs. The novel sequences showed $<70 \%$ of identity in the predicted whole genome and capsid protein amino acid (aa) sequence compared to the other members of the Circovirus genus (22). Taking into account the economic importance and the well-known effects of PCV-2 on the swine industry, a new member of the same family like PCV-3 should not be neglected. Studies on epidemiology, pathogenesis, immunity and diagnosis are guaranteed in the next few years, but the scientific community is still in its very beginning on the knowledge of this new infectious agent. Therefore, the objective of the present review is to update the current knowledge and forecast future trends on PCV-3.

\section{MOLECULAR ORGANIZATION OF PORCINE CIRCOVIRUSES}

Porcine circovirus 3 (PCV-3) belongs to the family Circoviridae, genus Circovirus. Until 2016, the Circoviridae family was divided into two different genera named Circovirus and Gyrovirus (23); however, on the basis of the viral structure and genome, a new taxonomical grouping has been recently established by the 
International Committee on Taxonomy of Virus. The genus Gyrovirus has been removed from the family Circoviridae and reassigned into the Anelloviridae family, and the new taxon Cyclovirus has been included into the Circoviridae family (24). This new genus is closely related with Circovirus genus members, with some differences in the genomic structure such as the orientation of the major open reading frames (ORFs). Moreover, viral sequences of the genus Cyclovirus have been reported in both vertebrates and invertebrates, including humans and other mammals (25-29), birds (30), and insects (31). Members of the Circovirus genus have been detected in vertebrates (32); most recently one study reported the presence of a Circovirus genome in invertebrates (33). One of the first Circovirus discovered, Psittacine beak and feather disease virus, was described in avian species (34) and, subsequently, several reports revealed the presence of similar virions in other species such as swine (35), fishes (36), bats (37-39), chimpanzees (40), dogs (41) humans (40), and minks (42). Since 2016, three species of porcine circoviruses have been formally accepted, including Porcine circovirus 1 (PCV-1), PCV-2 and PCV-3 $(21,22)$.

Structurally, circoviruses are small single-stranded DNA (ssDNA) viruses (43), characterized by a non-enveloped virion with icosahedral symmetry, and a circular genome with a diameter ranging from 13 to $25 \mathrm{~nm}$. Members of this family are constituted by 60 capsid protein subunits organized in a dodecahedral pentamer clustered unit (44). PCV-1 has a genome size ranging from 1,758 to 1,760 nucleotides (nt) (45-47), while the circular genomes of PCV-2 and PCV-3 consist of 1,766-1,769 and 1,999-2,001 nt, respectively $(21,46,48-50)$.

Porcine circoviruses contain three major ORFs arranged in the strands of the replicative form (RF) (21). For PCV-1, a total of seven putative ORFs capable to encode proteins larger than $5 \mathrm{kDa}$ have been predicted on both DNA strands (47), being six of them larger than $200 \mathrm{nt}(51,52)$. PCV-2 contains, besides the three major ORFs, eight more predicted ones, but just ORF4 has been characterized in more detail (53-55). PCV-3 contains so far three identified ORFs, but only ORF1 and ORF2 have been characterized. The general characteristics of the three major ORFs of PCVs are summarized in Table 1.

ORF1 encodes for Rep and $\mathrm{Rep}^{\prime}$ proteins involved in replication initiation, of 312 and 168 aa, respectively, in PCV1, and of 314 and 297 aa, respectively, for PCV-2 (56). ORF1 apparently codes for a single replicase protein in PCV-3, of 296297 aa $(21,22)$. ORF1 is located on the positive strand and considered the most conserved region of the circovirus genome (57). The origin of replication (ori), constituted by a conserved non-anucleotide motif $[(\mathrm{T} / \mathrm{n}) \mathrm{A}(\mathrm{G} / \mathrm{t}) \mathrm{TATTAC}]$, is located on the same strand as ORF1 and, consequently, this frame is involved in rolling circle replication (RCR) (58).

ORF2 encodes the only structural protein (Cap). It consists of 230-233 aa for PCV-1, 233-236 aa for PCV-2 $(56,59,60)$ and 214 aa for PCV-3 $(21,22)$. ORF2 is located on the negative DNA viral strand and Cap protein is considered the most variable (46, 61, 62), and most immunogenic (63) viral protein. Nucleotide similarity of $67 \%$ in Cap protein between PCV-1 and PCV-2 was detected through phylogenetic analyses (64); moreover, the similarity in this protein is much lower (24\%) among PCV-1 and PCV-3 (22) while being 26-37\% between PCV-2 and PCV-3 $(21,22)$.

The ORF3 is oriented in the opposite direction of ORF1, also in the negative strand, which codifies for a non-structural protein with apoptotic capacity $(56,65)$. The ORF3 protein consists of 206 aa for PCV-1, 104 aa for PCV-2 and 231 aa for PCV-3 $(21,66)$. The apoptotic activity of ORF3 protein has been described both in vitro and in vivo for PCV-1 and PCV-2 $(67,68)$, while its putative function in PCV-3 is still unknown.

Lastly, ORF4, also located in the negative strand, has only been described in the PCV-2 genome. This gene codifies for a protein of approximately 60 aa with anti-apoptotic function $(53,54)$.

Table 2 summarizes the nucleotide and amino acid raw distances (calculated by means of the median pairwise distances) among and within porcine circoviruses.

The similarity between PCV-3 sequences ranges from 97 to $100 \%$ throughout the analyzed years and tested countries $(48,69-$ 71). Phylogenetic analyses suggested two main groups classified as PCV-3a and PCV-3b and several sub-clusters (48, 72, 73), based on differences found between both groups in the aa sites 122 and 320 (S122A and A320V). In fact, certain antigenicity differences among groups have been proposed (74), although it is still too early to discuss about potential different genotypes or subgroups for PCV-3. Additionally, the progressive increase in sequence availability is revealing the presence of other branching patterns, which hardly fit with the "two genotype" classification. Therefore, similarly to PCV-2, a higher heterogeneity might be found in the future. A phylogenetic tree including full-length sequences of PCV-3 is depicted in Figure 1.

\section{EPIDEMIOLOGY}

After the first description reported from the USA, several countries located in Asia, Europe and South America (Figure 2) have demonstrated the presence of PCV-3 genome in domestic pig $(70,73,75-80)$.

PCV-3 genome has been detected at all tested ages, including sows, mummified fetuses and stillborn $(21,79,81)$. The frequency of viral detection found by PCR in pigs is variable according to the collected samples around the world (Table 3). A lower frequency of PCV-3 PCR positivity has been detected in lactating pigs when compared with nursery and fattening ones; the highest prevalence was found in animals after weaning $(48,77,82)$. However, these studies included different pigs from fairly limited age-groups and not the same animals over time. In a very recent work performed on longitudinally sampled pigs in Spain (83), PCV-3 DNA was found at all age-groups in four tested farms, and the frequency of infection was not clearly dominant at any age. Also, PCV-3 has been detected at moderate to high rate in sera pools from sows in Poland (77) and Thailand (84).

PCV-3 genome has been detected by PCR in oral fluids and nasal swabs $(76,82)$ as well as in feces $(85,95)$, semen $(70)$, and colostrum (84). Kedkovid et al. (84) found a positive correlation between detection in serum samples and in colostrum, suggesting that the colostrum is influenced by the viremic stage of the sow. No specific studies have been performed on the virus detection 
TABLE 1 | Summary of characteristics of the three major ORFs in PCV-1, PCV-2, and PCV-3.

\begin{tabular}{|c|c|c|c|c|c|c|c|}
\hline \multirow[t]{2}{*}{ Porcine circovirus } & \multirow[t]{2}{*}{ Size (nt) } & \multicolumn{2}{|c|}{ ORF1 } & \multicolumn{2}{|c|}{ ORF2 } & \multicolumn{2}{|c|}{ ORF3 } \\
\hline & & Protein & $\begin{array}{c}\text { Size } \\
\text { (aa) }\end{array}$ & Protein & Size (aa) & Protein & Size (aa) \\
\hline PCV-1 & $1,758-1,760$ & $\begin{array}{l}\text { Rep } \\
\text { Rep' }\end{array}$ & $\begin{array}{l}312 \\
168\end{array}$ & Cap & $230-233$ & NS & 206 \\
\hline PCV-2 & $1,766-1,769$ & $\begin{array}{l}\text { Rep } \\
\text { Rep' }\end{array}$ & $\begin{array}{l}314 \\
297\end{array}$ & Cap & 233-236 & NS & 104 \\
\hline PCV-3 & 1,999-2,001 & Rep & $\begin{array}{c}296- \\
297\end{array}$ & Cap & 214 & Unknown & 231 \\
\hline
\end{tabular}

NS, Non-structural protein; nt, nucleotides; aa, amino acids.

TABLE 2 | Median of pairwise genetic and amino acid distance calculated for all available PCV-1, PCV-2, and PCV-3 sequences.

\begin{tabular}{|c|c|c|c|c|c|c|c|c|c|c|}
\hline & & \multicolumn{3}{|c|}{ Complete genome } & \multicolumn{3}{|c|}{ Cap } & \multicolumn{3}{|c|}{ Rep } \\
\hline & & PCV-1 & PCV-2 & PCV-3 & PCV-1 & PCV-2 & PCV-3 & PCV-1 & PCV-2 & PCV-3 \\
\hline \multirow[t]{3}{*}{ DNA } & PCV-1 & $\begin{array}{c}0.011 \\
{[0.000-0.026]}\end{array}$ & $\begin{array}{c}0.228 \\
{[0.220-0.271]}\end{array}$ & $\begin{array}{c}0.533 \\
{[0.528-0.543]}\end{array}$ & $\begin{array}{c}0.017 \\
{[0.000-0.043]}\end{array}$ & $\begin{array}{c}0.332 \\
{[0.314-0.352]}\end{array}$ & $\begin{array}{c}0.598 \\
{[0.586-0.611]}\end{array}$ & $\begin{array}{c}0.006 \\
{[0.000-0.070]}\end{array}$ & $\begin{array}{c}0.174 \\
{[0.116-0.194]}\end{array}$ & $\begin{array}{c}0.500 \\
{[0.491-0.527]}\end{array}$ \\
\hline & PCV-2 & $\begin{array}{c}0.228 \\
{[0.220-0.271]}\end{array}$ & $\begin{array}{c}0.037 \\
{[0.001-0.102]}\end{array}$ & $\begin{array}{c}0.525 \\
{[0.518-0.544]}\end{array}$ & $\begin{array}{c}0.332 \\
{[0.314-0.352]}\end{array}$ & $\begin{array}{c}0.057 \\
{[0.000-0.172]}\end{array}$ & $\begin{array}{c}0.547 \\
{[0.539-0.569]}\end{array}$ & $\begin{array}{c}0.174 \\
{[0.116-0.194]}\end{array}$ & $\begin{array}{c}0.022 \\
{[0.000-0.056]}\end{array}$ & $\begin{array}{c}0.495 \\
{[0.485-0.520]}\end{array}$ \\
\hline & PCV-3 & $\begin{array}{c}0.533 \\
{[0.528-0.543]}\end{array}$ & $\begin{array}{c}0.525 \\
{[0.518-0.544]}\end{array}$ & $\begin{array}{c}0.009 \\
{[0.000-0.024]}\end{array}$ & $\begin{array}{c}0.598 \\
{[0.586-0.611]}\end{array}$ & $\begin{array}{c}0.547 \\
{[0.539-0.569]}\end{array}$ & $\begin{array}{c}0.014 \\
{[0.000-0.028]}\end{array}$ & $\begin{array}{c}0.500 \\
{[0.491-0.527]}\end{array}$ & $\begin{array}{c}0.495 \\
{[0.485-0.520]}\end{array}$ & $\begin{array}{c}0.006 \\
{[0.000-0.034]}\end{array}$ \\
\hline \multirow[t]{3}{*}{ Amino acid } & PCV-1 & NA & NA & NA & $\begin{array}{c}0.028 \\
{[0.000-0.071]}\end{array}$ & $\begin{array}{c}0.303 \\
{[0.283-0.346]}\end{array}$ & $\begin{array}{c}0.748 \\
{[0.732-0.760]}\end{array}$ & $\begin{array}{c}0.006 \\
{[0.000-0.075]}\end{array}$ & $\begin{array}{c}0.147 \\
{[0.088-0.194]}\end{array}$ & $\begin{array}{c}0.583 \\
{[0.577-0.607]}\end{array}$ \\
\hline & PCV-2 & NA & NA & NA & $\begin{array}{c}0.303 \\
{[0.283-0.346]}\end{array}$ & $\begin{array}{c}0.055 \\
{[0.000-0.177]}\end{array}$ & $\begin{array}{c}0.689 \\
{[0.681-0.736]}\end{array}$ & $\begin{array}{c}0.147 \\
{[0.088-0.194]}\end{array}$ & $\begin{array}{c}0.009 \\
{[0.000-0.075]}\end{array}$ & $\begin{array}{c}0.574 \\
{[0.564-0.602]}\end{array}$ \\
\hline & PCV-3 & NA & NA & NA & $\begin{array}{c}0.748 \\
{[0.732-0.760]}\end{array}$ & $\begin{array}{c}0.689 \\
{[0.681-0.736]}\end{array}$ & $\begin{array}{c}0.012 \\
{[0.000-0.035]}\end{array}$ & $\begin{array}{c}0.583 \\
{[0.577-0.607]}\end{array}$ & $\begin{array}{c}0.574 \\
{[0.564-0.602]}\end{array}$ & $\begin{array}{c}0.003 \\
{[0.000-0.031]}\end{array}$ \\
\hline
\end{tabular}

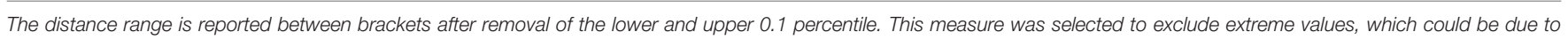
poor quality of some sequences challenging to be detected during alignment inspection. NA, non-applicable.

in the environment, but one study indicates that the virus was found in 2 out of 4 sponges used for sampling pig transporting trucks after sanitation (89).

Besides domestic pigs, PCV-3 infects wild boar. Viral DNA sequences retrieved from wild boar showed more than $98 \%$ similarity with the available sequences from domestic pigs (95, 96). The prevalence found in tested serum samples was similar or higher than that found in domestic pigs, ranging from 33 to $42.66 \%$. Additionally, infection susceptibility was associated with the age in both studies; juvenile animals were statistically less often PCV-3 PCR positive than the older ones. In fact, a potential reservoir role of the wild boar with respect to PCV-3 infection has been suggested $(95,96)$.

PCV-3 seems to be restricted to Suidae species. However, PCV-3 genome has been found in 4 out of 44 (9.09\%) serum samples of dogs from China. The authors suggested that the virus might infect, therefore, non-porcine species (97). To date, there is no further evidence regarding susceptibility to PCV-3 infection in other species.

\section{DISEASE ASSOCIATION WITH PCV-3}

PCV-3 has been detected in pigs with different clinical/ pathological conditions, such as respiratory, reproductive, gastrointestinal and neurological disorders; however, the virus has been also detected in apparently healthy animals $(21,71,98)$. The conditions in which PCV-3 has been found are summarized in Table 4. Noteworthy, in most of these scenarios there are not complete diagnostic studies, but only the detection of the viral genome in a number of pigs affected by different clinical signs. Even though the viral genome was detected, it is worthy to state that it does not imply a causative role of PCV-3 in the observed condition. Thus, this section compiles the peer-reviewed papers, reporting PCV-3 DNA detection in different disease scenarios.

The amount of viral DNA in serum samples $\left(10^{2}-10^{7}\right.$ copies $/ \mathrm{mL})(21)$ and tissues $\left(10^{4}-10^{11}\right.$ copies $\left./ \mathrm{mg}\right)(86,91)$ in postweaning pigs and adults was rather variable, as well as in stillborn or fetal tissues $\left(10^{6}-10^{9}\right.$ copies/mg) $(21,75)$. In most of these cases, the number of PCV-3 genome copies should be considered moderate to low $(21,91)$. In addition, detection was possible in some instances, but the viral load was below the limit of quantification of the qPCR, which may emphasize the subclinical nature of the infection in these cases $(48,81)$. An association between high viral load and severity has been demonstrated for other porcine circovirus (PCV-2), especifically under PCV-2-SD (102) and PCV-2-reproductive disease (103) scenarios. However, the meaning of a given genome 


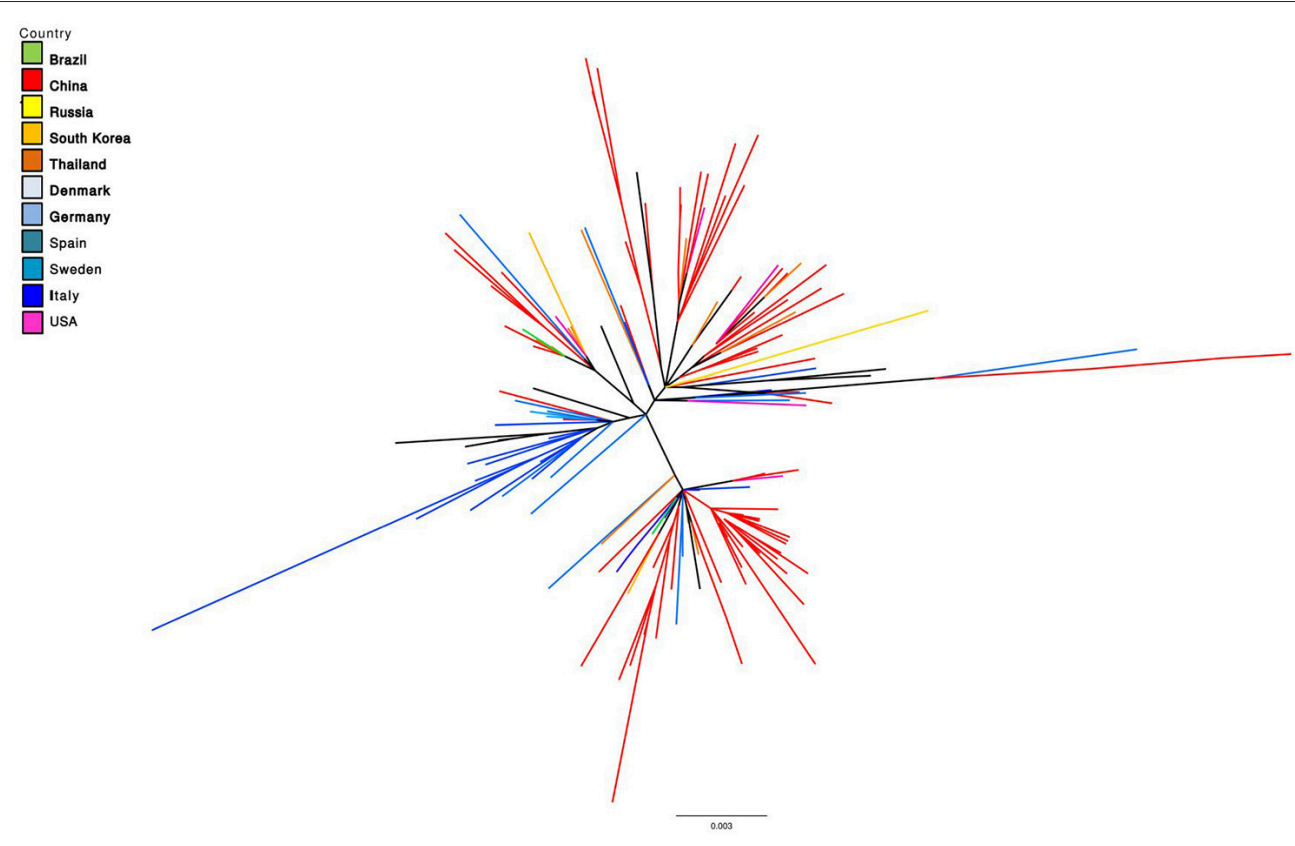

FIGURE 1 | Maximum Likelihood unrooted phylogenetic tree reconstructed based on all available PCV-3 complete genome sequences (retrieved on October 2018). Tree terminal branches have been color coded according to the corresponding collection country. Black color in terminal branches indicates other countries not included in the list.

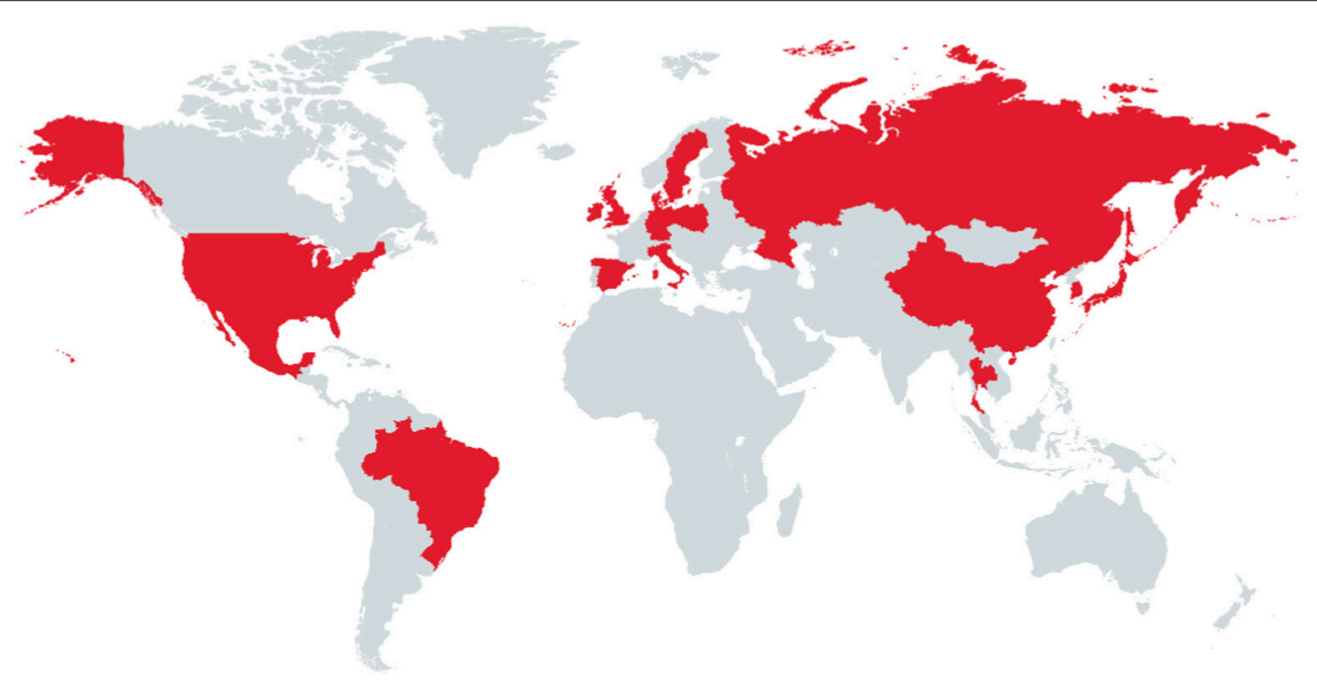

FIGURE 2 | Countries in red are those that have been so far reported PCV-3 PCR positive samples in domestic pig.

viral load for PCV-3 in healthy or diseased pigs is still to be elucidated.

\section{Reproductive Disease}

PCV-3 genome was initially retrieved from sows with clinical signs compatible with PDNS in USA. In the affected farm, a decrease of $0.6 \%$ in the conception rate was found while the sow mortality showed a $10.2 \%$ increase (21). In China, PCV3 was found in serum samples from sows with reproductive problems characterized by acute loss of neonatal piglets (70). Moreover, a comparative study between healthy sows and sows with a clinical picture characterized by chronic reproductive failure (including increase in abortion and sow mortality rates) revealed that PCV-3 positivity was higher in affected sows (39 out of $84,46.42 \%$ ) than in healthy ones (23 out of $105,21.9 \%$ ) (69). Viral genome has also been found in tissues from stillborn in farms experiencing reproductive failure in China (69-71) and Korea (94). 
TABLE 3 | Reports describing PCV-3 frequency of detection on different countries and sample types.

\begin{tabular}{|c|c|c|c|c|c|}
\hline References & Country & Sample type & PCV-3 positive (n) & Tested samples ( $n$ ) & Frequency of detection (\%) \\
\hline Collins et al. (85) & Ireland & Tissue and feces & 52 & 313 & 16.61 \\
\hline Fu et al. (73) & China & Tissue and stillborn & 76 & 285 & 26.67 \\
\hline Kwon et al. (82) & South Korea & Oral fluid & 159 & 360 & 44.17 \\
\hline Ku et al. (70) & China & Tissue, stillborn, semen and serum & 77 & 222 & 34.68 \\
\hline Palinski et al. (21) & USA & Serum & 47 & 150 & 31.33 \\
\hline Stadejek et al. (77) & Poland & Serum & 55 & 215 & 25.58 \\
\hline Xu et al. (86) & China & Tissue and serum & 53 & 170 & 31.18 \\
\hline Zhai et al. (87) & China & Tissue and serum & 84 & 506 & 16.60 \\
\hline Zheng et al. (71) & China & Tissue & 132 & 222 & 59.46 \\
\hline Wen et al. (88) & China & Tissue and serum & 50 & 155 & 32.26 \\
\hline $\begin{array}{l}\text { Klaumann et al. } \\
\text { (81) }\end{array}$ & Spain & Serum & 75 & 654 & 11.47 \\
\hline Franzo et al. (89) & Italy & Sponge sample & 2 & 4 & 50.00 \\
\hline Franzo et al. (76) & Denmark & Tissue and serum & 44 & 78 & 56.41 \\
\hline Franzo et al. (76) & Italy & Tissue and serum & 36 & 91 & 39.56 \\
\hline Franzo et al. (76) & Spain & Serum (pools) & 14 & 94 & 14.89 \\
\hline Hayashi et al. (90) & Japan & Tissue & 7 & 73 & 9.59 \\
\hline $\begin{array}{l}\text { Kedkovid et al. } \\
\text { (84) }\end{array}$ & Thailand & Colostrum & 17 & 38 & 44.74 \\
\hline $\begin{array}{l}\text { Kedkovid et al. } \\
\text { (91) }\end{array}$ & Thailand & Tissues and serum & 33 & 103 & 32.04 \\
\hline Sun et al. (78) & China & Tissue & 13 & 200 & 6.50 \\
\hline Zou et al. (69) & China & Serum & 62 & 190 & 32.63 \\
\hline Zhao et al. (92) & China & Tissue & 40 & 272 & 14.71 \\
\hline Ye et al. (93) & Sweden & Tissue & 10 & 49 & 20.41 \\
\hline Kim et al. (94) & Korea & Serum & 37 & 286 & 17.9 \\
\hline Kim et al. (94) & Korea & Tissue & 20 & 296 & 6.8 \\
\hline
\end{tabular}

\section{Respiratory Disease}

PCV-3 DNA was also detected in pigs with respiratory disorders, as already indicated in the first report of this virus (21). Two more studies reported PCV-3 genome in animals from China with abdominal breathing and lesions including lung swelling and congestion $(87,99)$. More recently, the viral genome has been detected in fattening pigs from Thailand suffering from porcine respiratory disease complex (PRDC), characterized by coughing, dyspnea, fever and anorexia; the prevalence was higher in diseased animals $(60 \%$; 15 out of 25$)$ than in healthy ones $(28 \%$; 7 out of 25) (91).

\section{Other Conditions}

Multisystemic inflammation and myocarditis were initially linked with the presence of PCV-3 (22). One single study described PCV-3 in weaned pigs that suffered from gastrointestinal disorders (diarrhea), showing higher prevalence in pigs with clinical signs (17.14\%, 6 out of 35) compared to those with non-diarrhea signs (2.86\%; 1 out of 35) (87). In another report, animals with congenital tremors were analyzed and PCV-3 was the only pathogen found in the brain, with high amount of viral DNA (101).

\section{Healthy Animals}

A number of studies found PCV-3 in apparently healthy animals $(69,76,81,87,93)$, which makes much more complicated the overall interpretation of this virus as potential causative agent of disease.

\section{Co-infections}

Whilst the initially PCV-3 PCR positive cases were negative for three of the most important swine infectious agents (PCV-2, PRRSV, and Porcine parvovirus, PPV) $(21,22,87)$, subsequent studies revealed frequent co-infection with other viruses. All pathogens found in co-infections with PCV-3 are summarized in Table 5.

It is still too early to establish the overall picture of PCV-3 infection, since it is a widespread virus in healthy animals. Therefore, the likelihood of disease may not depend on its presence only, but other factors may serve as illness triggering factors or up-regulate its replication under disease scenarios.

\section{LABORATORY TOOLS TO DETECT PCV-3}

The detection of the virus is currently based on molecular techniques such as conventional PCR and qPCR and its characterization by Sanger sequencing or NGS. In fact, the first PCV-3 complete genome was identified by NGS, and subsequently Sanger sequencing has been systematically applied to obtain novel PCV-3 sequences. Several primer 
TABLE 4 | Clinical signs reported in PCV-3 PCR positive animals according to production phase in different clinical/pathological scenarios.

\begin{tabular}{|c|c|c|c|c|}
\hline Disorders & $\begin{array}{l}\text { Production } \\
\text { phase }\end{array}$ & Clinical signs - disease & $\begin{array}{l}\text { Control } \\
\text { group-healthy } \\
\text { animals }\end{array}$ & Reference \\
\hline Reproductive & Sows & $\begin{array}{l}\text { - Increase in the sow mortality; decrease in the conception } \\
\text { rates; mummified fetuses } \\
\text { - Aborted fetuses, stillborn } \\
\text { - Abortion, mummified fetuses; reproductive failure; } \\
\text { decrease of neonatal rate }\end{array}$ & $\begin{array}{l}\text { NA } \\
\text { NA } \\
\text { NA }\end{array}$ & $\begin{array}{l}\text { Palinski et al. (21) } \\
\text { Faccini et al. (75) } \\
\text { Ku et al. (70) }\end{array}$ \\
\hline Respiratory & $\begin{array}{l}\text { Lactation } \\
\text { Weaning } \\
\text { Weaning } \\
\text { Fattening } \\
\text { Fattening }\end{array}$ & $\begin{array}{l}\text { - Dyspnea } \\
\text { - Anorexia, fever, icterus, abdominal breathing } \\
\text { - Cough, softly panting, abdominal breathing } \\
\text { - Respiratory signs } \\
\text { - Porcine respiratory disease complex (PRDC) }\end{array}$ & $\begin{array}{l}\text { NA } \\
\text { NA } \\
\text { Yes* }^{*} \\
\text { NA } \\
\text { NA }\end{array}$ & $\begin{array}{l}\text { Phan et al. (22) } \\
\text { Shen et al. (99) } \\
\text { Zhai et al. (87) } \\
\text { Phan et al. (22) } \\
\text { Kedkovid et al. (91) }\end{array}$ \\
\hline Cardiovascular & Weaning & - Anorexia, weight loss, swollen joints & NA & Phan et al. (22) \\
\hline Gastrointestinal & Weaning & - Diarrhea & Yes* $^{\star}$ & Zhai et al. (87) \\
\hline Systemic & Weaning & $\begin{array}{l}\text { - Wasting } \\
\text { - Periweaning failure-to-thrive syndrome (PFTS) }\end{array}$ & $\begin{array}{l}\text { Yes }^{\star} \\
\text { Yes }^{\star}\end{array}$ & $\begin{array}{l}\text { Stadejek et al. (77) } \\
\text { Franzo et al. (100) }\end{array}$ \\
\hline Neurological & $\begin{array}{l}\text { Lactation } \\
\text { Lactation }\end{array}$ & $\begin{array}{l}\text { - Neurological signs } \\
\text { - Congenital tremors }\end{array}$ & $\begin{array}{l}\text { NA } \\
\text { NA }\end{array}$ & $\begin{array}{l}\text { Phan et al. (22) } \\
\text { Chen et al. (101) }\end{array}$ \\
\hline Others & $\begin{array}{l}\text { Fattening } \\
\text { Sows }\end{array}$ & $\begin{array}{l}\text { - Rectal prolapse } \\
\text { - PDNS }\end{array}$ & $\begin{array}{l}\text { NA } \\
\text { NA }\end{array}$ & $\begin{array}{l}\text { Phan et al. (22) } \\
\text { Palinski et al. (21) }\end{array}$ \\
\hline
\end{tabular}

NA, not available in the published study; ${ }^{*}$, PCV-3 positivity in lower frequency than diseased animals.

pairs and probes have been designed for these molecular techniques $(21,89,101)$. Moreover, a duplex qPCR for the simultaneous detection of PCV-2 and PCV-3 has been also attempted (105).

In situ hybridization, a technique used to detect viral genome on histological tissue sections, has been performed in two studies $(22,91)$. However, the technique is not yet completely standardized, since it is still used in minimal number of laboratories worldwide and a thorough description of the infected cell types is still missing.

A minimum number of studies showed the development and validation of serological tests. Two reports have published limited information about indirect enzyme-linked immunosorbent (ELISA) tests using recombinant PCV3 Cap protein $(21,106)$. More recently, a PCV-3 specific monoclonal antibody has been produced, presumably working on formalin-fixed, paraffin-embedded tissues by means of immunohistochemistry (72).

Infection of cell cultures with PCV-3 tissue homogenates has been attempted in PK-15 (21, 75) and swine testicle cells (ST) (21) without success. The cells were observed for cytopathic effects and monitored by qPCR for viral growth. However, the Ct-values did not increase at each cellular passage and no cytopathic effect was observed $(21,75)$. Therefore, there is not any PCV-3 isolate so far available.

Definitely, in order to elucidate the PCV-3 pathogenesis, further establishment of laboratory techniques such as viral isolation, serology, and detection of viral components in tissues is needed. In consequence, the potential association of PCV-3 with any clinical condition, if any, is difficult to be demonstrated due to existing technical limitations.

\section{KNOWLEDGE GAPS OF PCV-3 INFECTION PCV-3 As a Cause of Disease}

Porcine circoviruses (PCVs) are ssDNA ubiquitous viruses, widespread worldwide in the domestic pig population (107). Two species were known to infect Suidae species before 2015: PCV-1, considered non-pathogenic, and PCV-2, the cause of one of the most devastating porcine diseases, PCV-2-SD. PCV-3 represents an expansion of the swine virosphere within the Circoviridae family, but the up-to-date knowledge is still very limited and there is not yet any clue on its potential pathogenesis or disease causation role. It is at least curious that 20 years ago there were serious doubts about PCV-2 as a cause of an overt disease characterized by severe lesions and high mortality (108), while nowadays PCV-3 has been found within a number of clinical conditions and putative association has been established from the very beginning $(21,22)$.

Current literature has already reported the presence of PCV3 in animals affected by different clinical pictures, although just few of them included healthy control groups $(71,76,87,91)$. In all studies, the frequency of PCV-3 detection in diseased animals was higher; although these results did not prove any disease causality, at least open the avenue to definitively ascertain its role in clinical/pathological manifestations. Further studies on potential disease association of PCV-3 are needed.

\section{Pathogenesis}

No data is available regarding the pathogenesis of PCV3 infection. The lack of virus isolation has impeded the establishment of an infection model to date. It is known that PCV-3 can be found in different tissues of domestic pig and wild boar $(86,87,95)$, indicating the systemic nature of the 
TABLE 5 | Pathogens present in PCV-3 PCR positive samples/cases.

\begin{tabular}{|c|c|c|}
\hline Pathogen & $\begin{array}{l}\text { Frequency of } \\
\text { co-infection (percentage) }\end{array}$ & Reference \\
\hline PCV-2 & $\begin{array}{l}38 / 200(19 \%) \\
28 / 40(70 \%) \\
35 / 222(15.77 \%) \\
13 / 46(28.26 \%) \\
1 / 8(12.5 \%) \\
11 / 57(19.3 \%)\end{array}$ & $\begin{array}{l}\text { Sun et al. (78) } \\
\text { Zhao et al. (92) } \\
\text { Ku et al. (70) } \\
\text { Kim et al. (104) } \\
\text { Kedkovid et al. (91) } \\
\text { Kim et al. (94) }\end{array}$ \\
\hline PRRSV & $\begin{array}{l}1 / 8(12.5 \%) \\
25 / 57(43.86 \%)\end{array}$ & $\begin{array}{l}\text { Kedkovid et al. (91) } \\
\text { Kim et al. (94) }\end{array}$ \\
\hline $\begin{array}{l}\text { Torque teno sus virus } \\
\text { (TTSuV1 and 2) }\end{array}$ & $66 / 132$ (50\%) & Zheng et al. (78) \\
\hline $\begin{array}{l}\text { Classical swine fever virus } \\
\text { (CSFV) }\end{array}$ & $108 / 200$ (54\%) & Sun et al. (78) \\
\hline Porcine bocavirus (PBoV) & NA & Chen et al. (101) \\
\hline $\begin{array}{l}\text { Porcine epidemic diarrhea } \\
\text { virus (PEDV) }\end{array}$ & NA & Chen et al. (101) \\
\hline $\begin{array}{l}\text { Atypical porcine pestivirus } \\
\text { (APPV) }\end{array}$ & NA & Chen et al. (101) \\
\hline $\begin{array}{l}\text { Porcine deltacoronavirus } \\
\text { (PDCoV) }\end{array}$ & NA & Chen et al. (101) \\
\hline Porcine kobuvirus (PKV) & NA & Chen et al. (101) \\
\hline $\begin{array}{l}\text { Porcine pseudorabies virus } \\
\text { (PRV) }\end{array}$ & NA & Chen et al. (101) \\
\hline Porcine sapelovirus (PSV) & NA & Chen et al. (101) \\
\hline Porcine parvovirus (PPV) & NA & Franzo et al. (100) \\
\hline $\begin{array}{l}\text { Ungulate bocaparvovirus } 2 \\
\text { (BoPV2) }\end{array}$ & NA & Franzo et al. (100) \\
\hline Pasteurella multocida & NA & Kedkovid et al. (91) \\
\hline Haemophilus parasuis & NA & Phan et al. (22) \\
\hline Streptococcus suis & NA & Phan et al. (22) \\
\hline Mycoplasma hyorhinis & NA & Phan et al. (22) \\
\hline
\end{tabular}

NA, not available in the published study.

infection. However, the point of viral entry, primary replication, organic distribution and persistence are still unsolved issues. PCV-3 has been found in feces, nasal swabs, oral fluids, and trucks transporting pigs $(82,85,95)$, which allows speculating that horizontal transmission through direct contact is probably an important route. Detection of viral genome in fetuses and stillborn from farms with history of reproductive failure $(21,70$, $75)$, as well as in semen and colostrum, points out also to vertical transmission as another likely route. Definitively, more studies are needed to ascertain the potential excretion routes of this virus.

\section{Co-infections}

Co-infection of PCV-3 with both PCV-2 and PRRSV has been reported $(70,78,91,92,94)$. In fact, this was expected since both well-known pathogens are widespread in the pig population (109-111). Noteworthy, it is known that both PCV-2 and PRRSV are able to affect the immune system and, therefore, co-infections with these viruses are not unusual $(112,113)$. Other pathogens were also detected in PCV-3 PCR positive samples $(78,114)$. Very recently, PCV-3 has been found by NGS approach in pigs affected by periweaning failure-to-thrive syndrome in co-infection with PPV and Ungulate bocaparvovirus 2 (100). Since experimental and field studies demonstrated that co-infection with PPV increase the effect of PCV-2 in causing PCV-2-SD (115), at this point it cannot be ruled out that a similar effect may occur with PCV-3. Further investigations are needed to determine whether PCV-3 might act as a secondary agent upregulating its replication once pigs are immunosuppressed or immunomodulated, or whether the frequency of co-infection is independent of the immune system affection.

\section{Age of Infection and Transmission}

Although PCV-3 genome has been detected at higher prevalence in weaned pigs $(48,77,82)$, only one study has monitored PCV-3 infection longitudinally (83). In this study, PCV-3 was found in pigs at all ages with a similar frequency. This infection dynamics contrasts with that of PCV-2, which infects pigs mainly between five and 12 weeks of age, and rarely in animals at the lactation phase (116-118). This is explained by the fact that colostrum antibodies are protective against infection and then decline during the lactation and weaning phases. Once maternally derived antibodies waned, an infection is followed by active seroconversion (117-119). This seroconversion usually occurs between 9 and 15 weeks of age and the antibodies may last until 28 weeks of age at least $(117,120-122)$. Regrettably, information about infection in sows, maternally derived immunity and how protective the immunity might be against PCV-3 is completely lacking at this moment. It is known that PCV-3 can be found in colostrum (84), implying the possibility of vertical transmission (sow to piglet) and emphasizing the potential importance of early infections. Again, available information regarding these issues on PCV-3 is still to be generated.

\section{Persistent or Long Lasting Infection}

One study performed in samples from captured and re-captured wild boar revealed long-lasting infection (potential persistent infection), since the virus was detected during a period of at least 5-7 months in few animals (95). Susceptibility of wild boar to PCV-3 was not a surprise, since this species shows susceptibility to several pathogens that affect humans and animals (123), including PCV-2; moreover, the wild boar can also develop PCV2-SD (124). Taking into account the potential long period of infection observed in some animals and even a higher overall prevalence in wild boar when compared with domestic pigs, such potential reservoir role deserves further investigations (95, 96).

\section{Spectrum of Species Infected and Public Health Issues}

Infection of PCV-3 in other non-Suidae species is, at this point, still to be demonstrated. Although PCV-3 DNA has been found in sera from dogs in China (97), the lack of other detection techniques able to confirm a true infection with this virus prevents the assumption of multiple species susceptibility.

Another interesting aspect yet currently unknown is the potential impact of PCV-3 on public health. DNA from PCV1 and PCV-2 has been found in vaccines intended for use in humans (125), probably associated to the use of reagents from 
swine origin in the vaccine manufacturing. At this point, no information regarding $\mathrm{PCV}-3$ and its role as a contaminant of human medicines do exist. On the other hand, porcine circoviruses belong to a group of microorganisms that still has not been fully addressed in terms of risk evaluation for xenotransplantation (126), so, PCV-3 should be also a priori added to such list.

\section{Origin, Evolution, and Phylogeny}

Palinski et al. (21) conducted a brief study in paraffin fixed tissues from 2010 to 2016 in North America and results showed a high percentage of PCR positivity in these samples, suggesting that the virus emerged before the year of its discovery. In fact, PCV3 has been already demonstrated retrospectively in Sweden in 1993 (93) and Spain (81) and China in 1996 (78), indicating that this is not a new virus and it has been circulating during several decades in domestic pigs. Moreover, PCV-3 has been detected in the oldest samples so far tested in these studies, suggesting that this virus could have been infecting pigs for even a longer period. However, these findings cannot be assumed as a proof of non-pathogenicity, especially when mirroring another closely-related circovirus, PCV-2. Although this latter virus was initially detected in association with disease by midlate 1990s, retrospective studies showed evidence of pig infection a number of decades before (120, 127-129). In fact, in most of these investigations, evidence of PCV-2 infection coincided with the very first investigated year, suggesting again that PCV2 might be even an older circulating virus. In addition, a retrospective study on PCV-3 conducted in samples of wild boar from Spain during a 14-year period (95) detected the virus in the first tested year (2004). Overall, obtained data confirmed that PCV-3 is not a new virus and has been circulating for a fairly, non-determined long time in swine and wild boar populations. In fact, the most common ancestor of PCV-3 was estimated to be originated approximately in 1966 (73, 130).

Genetic characterization of PCV-3 is mainly done through Sanger sequencing. Phylogenetic analyses of PCV-3 genomes available from the GenBank indicate they are part of different clusters. However, nucleotide identity among these sequences is really high $(>97 \%)$. In consequence, it seems that PCV-3 has remained fairly stable over the years without an independent molecular evolution according to specific areas of the world. Moreover, these findings do not point out a high mutation rate as has been suggested $(48,131)$. If such mutation rate were high, it would have generated a higher genomic heterogeneity, which should have been detected at least in the performed retrospective studies accounting for more than 20 years. Further studies on the evolution on PCV-3 are crucial to solve out these controversies.

The first metagenomics sequence available from PCV-3 revealed low identity with cap and rep genes of PCV-1 and PCV2 and a closer identity with other Circoviruses such as Canine circovirus $(21,22)$ and Barbel circovirus (71). The Circovirus genus members are able to infect a wide range of hosts, and cross-species transmission has also been reported (40). Franzo and collaborators (132) hypothesized the possibility of PCV-3 being the product of recombination related with a host jump. The analysis of genome composition of PCV-3 found the rep gene closely related with that of bat circoviruses and cap gene with that of avian ones (132). Recently, novel circoviruses isolated in civets, showing higher similarity in terms of aa sequence in Rep protein with PCV-3, have been described (133). The increasing new data should be useful to clarify the relationships and origin of this virus. On the other hand Fux et al. (48) found nucleotide changes, which resulted in two aa alterations in ORF1/ORF2 and ORF3 (A24V and R27K), between the two proposed genotypes (PCV$3 \mathrm{a}$ and PCV3b). Li et al. (131) also suggested two groups with two individual subclades termed PCV-3a-1 and PCV-3a-2. The aa site 24 from ORF2, predicted to be under positive selection, was suggested to be located in a potential epitope region. The presence of possible genotypes was also suggested in other studies $(73,76)$. However, considering the high similarity found in partial or complete PCV-3 sequences ( $>98 \%$ in most of the cases), the importance of determining genotypes or groupings at this stage seems poorly relevant. Due to the sensitivity limitations of Sanger sequencing, it must be emphasized the need to apply NGS technology to discover minor variants, which might unravel the presence of quasispecies undetected by the currently used technology.

\section{CONCLUSIONS}

Porcine circovirus 3 is a recently discovered virus widespread in both domestic pigs and wild boar population. The virus can be found at all tested ages and few animals may display a persistent infection. Although the virus has been found in several clinical and pathological conditions, a definitive proof of its pathogenicity is still lacking. Phylogenetic information available to date indicates a low genetic variability of PCV3 in comparison with other single stranded-DNA viruses and indicates that the virus genome has been relatively stable across the years.

\section{AUTHOR CONTRIBUTIONS}

FK and JS did the majority of the writing and communicated with the coauthors to coordinate the document editing. IS designed the outline of the manuscript. GF provided the phylogenetic analyses. FC-F, GF, MS, and JN revised the manuscript, did partial writing and approved the final version for publication.

\section{ACKNOWLEDGMENTS}

We would like to acknowledge the funding of the E-RTA201700007-00-00 project, from the Instituto Nacional de Investigación y Tecnologia Agraria y Alimentaria (Spanish Government). The funding from CERCA Programme/Generalitat de Catalunya to IRTA is also acknowledged. 


\section{REFERENCES}

1. Davies PR. One World, One Health: the threat of emerging swine diseases. A north american perspective. Transbound Emerg Dis. (2012) 59:18-26. doi: 10.1111/j.1865-1682.2012.01312.x

2. Witzany G. Natural genome-editing competences of viruses. Acta Biotheor. (2006) 54:235-53. doi: 10.1007/s10441-006-9000-7

3. Edfors-Lilja I, Wattrang E, Marklund L, Moller M, Andersson-Eklund L, Andersson L, et al. Mapping quantitative trait loci for immune capacity in the pig. IImmunol. (1998) 161:829-35.

4. Conway DJ, Roper C. Micro-evolution and emergence of pathogens. Int J Parasitol. (2000) 30:1423-30. doi: 10.1016/S0020-7519(00)00126-0

5. Holmes EC, Rambaut A. Viral evolution and the emergence of SARS coronavirus. Philos Trans R Soc B Biol Sci. (2004) 359:1059-65. doi: 10.1098/rstb.2004.1478

6. Woolhouse MEJ, Taylor LH, Haydon DT. Population biology of multihost pathogens. Science (2001) 292:1109-12. doi: 10.1126/science.1059026

7. La Rosa G, Fratini M, della Libera S, Iaconelli M, Muscillo M. Emerging and potentially emerging viruses in water environments. Ann Ist Super Sanità (2012) 48:397-406. doi: 10.4415/ANN_12_04_07

8. Nichol ST, Arikawa J, Kawaoka Y. Emerging viral diseases. Proc Natl Acad Sci USA. (2000) 97:12411-2. doi: 10.1073/pnas.210382297

9. Correa-Fiz F, Franzo G, Llorens A, Segalés J, Kekarainen T. Porcine circovirus 2 (PCV-2) genetic variability under natural infection scenario reveals a complex network of viral quasispecies. Sci Rep. (2018) 8:15469. doi: 10.1038/s41598-018-33849-2

10. Fournié G, Kearsley-Fleet L, Otte J, Pfeiffer DU. Spatiotemporal trends in the discovery of new swine infectious agents. Vet Res. (2015) 46:114. doi: 10.1186/s13567-015-0226-8

11. Canning P, Canon A, Bates JL, Gerardy K, Linhares DCL, Piñeyro PE, et al. Neonatal mortality, vesicular lesions and lameness associated with senecavirus A in a U.S. Sow Farm. Transbound Emerg Dis. (2016) 63:373-8. doi: $10.1111 /$ tbed.12516

12. Wang L, Byrum B, Zhang Y. Detection and genetic characterization of deltacoronavirus in pigs, Ohio, USA, 2014. Emerg Infect Dis. (2014) 20:1227-30. doi: 10.3201/eid2007.140296

13. Lan D, Ji W, Yang S, Cui L, Yang Z, Yuan C, Hua X. Isolation and characterization of the first Chinese porcine sapelovirus strain. Arch Virol. (2011) 156:1567. doi: 10.1007/s00705-011-1035-7

14. Narayanappa A, Sooryanarain H, Deventhiran J, Cao D, Ammayappan Venkatachalam B, Kambiranda D, et al. A novel pathogenic mammalian orthoreovirus from diarrheic pigs and swine blood meal in the United States. MBio (2015) 6:e00593-15. doi: 10.1128/mBio.00593-15

15. Postel A, Hansmann F, Baechlein C, Fischer N, Alawi M, Grundhoff A, et al. Presence of atypical porcine pestivirus (APPV) genomes in newborn piglets correlates with congenital tremor. Sci Rep. (2016) 6:27735. doi: 10.1038/srep27735

16. Pan Y, Tian X, Qin P, Wang B, Zhao P, Yang Y-L, et al. Discovery of a novel swine enteric alphacoronavirus (SeACoV) in southern China. Vet Microbiol. (2017) 211:15-21. doi: 10.1016/j.vetmic.2017.09.020

17. Meng XJ. Emerging and re-emerging swine viruses. Transbound Emerg Dis. (2012) 59:85-102. doi: 10.1111/j.1865-1682.2011.01291.x

18. Song D, Chen Y, Peng Q, Huang D, Zhang T, Huang T, et al. Fulllength genome sequence of a variant porcine epidemic diarrhea virus strain, $\mathrm{CH} / \mathrm{GDZQ} / 2014$, responsible for a severe outbreak of diarrhea in piglets in guangdong, China, 2014. Genome Announc. (2014) 2:e01239-14. doi: 10.1128/genomeA.01239-14

19. Liang H, Su S, Deng S, Gu H, Ji F, Wang L, et al. The prevalence of hepatitis e virus infections among swine, swine farmers and the general population in guangdong province, China. PLoS ONE (2014) 9:e88106. doi: 10.1371/journal.pone.0088106

20. Christensen PB, Engle RE, Hjort C, Homburg KM, Vach W, Georgsen J, et al. Time trend of the prevalence of hepatitis e antibodies among farmers and blood donors: a potential zoonosis in denmark. Clin Infect Dis. (2008) 47:1026-31. doi: 10.1086/591970

21. Palinski R, Piñeyro P, Shang P, Yuan F, Guo R, Fang $Y$, et al. A novel porcine circovirus distantly related to known circoviruses is associated with porcine dermatitis and nephropathy syndrome and reproductive failure. J Virol. (2017) 91:e01879-16. doi: 10.1128/JVI.01 879-16

22. Phan TG, Giannitti F, Rossow S, Marthaler D, Knutson T, Li L, et al. Detection of a novel circovirus PCV3 in pigs with cardiac and multi-systemic inflammation. Virol J. (2016) 13:184. doi: 10.1186/s12985-016-0642-z

23. Pringle CR. Virus Taxonomy at the XIth international congress of virology, sydney, australia, 1999. Arch Virol. (1999) 144:2065-70. doi: $10.1007 / \mathrm{s} 007050050728$

24. Rosario K, Breitbart M, Harrach B, Segalés J, Delwart E, Biagini P, et al. Revisiting the taxonomy of the family circoviridae: establishment of the genus Cyclovirus and removal of the genus Gyrovirus. Arch Virol. (2017) 162:1447-63. doi: 10.1007/s00705-017-3247-y

25. Phan TG, Mori D, Deng X, Rajidrajith S, Ranawaka U, Ng TFF, et al. Small viral genomes in unexplained cases of human encephalitis, diarrhea, and in untreated sewage. Virology (2015) 482:98-104. doi: 10.1016/j.virol.2015.03.011

26. Sato G, Kawashima T, Kiuchi M, Tohya Y. Novel cyclovirus detected in the intestinal contents of Taiwan squirrels (Callosciurus erythraeus thaiwanensis). Virus Genes. (2015) 51:148-51. doi: 10.1007/s11262-015-1217-6

27. Zhang W, Li L, Deng X, Kapusinszky B, Pesavento PA, Delwart E. Faecal virome of cats in an animal shelter. J Gen Virol. (2014) 95:2553-64. doi: 10.1099/vir.0.069674-0

28. Smits SL, Zijlstra EE, van Hellemond JJ, Schapendonk CME, Bodewes R, Schürch AC, et al. Novel cyclovirus in human cerebrospinal fluid, malawi, 2010-2011. Emerg Infect Dis. (2013) 19:1511-3. doi: 10.3201/eid1909.130404

29. Ge X, Li J, Peng C, Wu L, Yang X, Wu Y, et al. Genetic diversity of novel circular ssDNA viruses in bats in China. J Gen Virol. (2011) 92:2646-53. doi: 10.1099/vir.0.034108-0

30. Li L, Shan T, Soji OB, Alam MM, Kunz TH, Zaidi SZ, et al. Possible crossspecies transmission of circoviruses and cycloviruses among farm animals. J Gen Virol. (2011) 92: doi: 10.1099/vir.0.028704-0

31. Dayaram A, Potter KA, Moline AB, Rosenstein DD, Marinov M, Thomas JE, et al. High global diversity of cycloviruses amongst dragonflies. J Gen Virol. (2013) 94:1827-1840. doi: 10.1099/vir.0.052654-0

32. Lukert P, de Boer GF, Dale JL, Keese P, McNulty MS, Randles JW, et al. The Circoviridae, In: Virus Taxonomy. Sixth Report of the International Committee on Taxonomy of Viruses, 166-168.

33. Wang B, Sun LD, Liu HH, Wang ZD, Zhao YK, Wang W, et al. Molecular detection of novel circoviruses in ticks in northeastern China. Ticks Tick Borne Dis. (2018) 9:836-839. doi: 10.1016/j.ttbdis.2018.03.017

34. Ritchie BW, Niagro FD, Lukert PD, Steffens WL, Latimer KS. Characterization of a new virus from cockatoos with psittacine beak and feather disease. Virology (1989) 171:83-88. doi: 10.1016/0042-6822(89)90513-8

35. Todd D. Circoviruses: immunosuppressive threats to avian species: a review. Avian Pathol. (2000) 29:373-94. doi: 10.1080/030794500750047126

36. Lorincz M, Dán Á, Láng M, Csaba G, Tóth ÁG, Székely C, et al. Novel circovirus in European catfish (Silurus glanis). Arch Virol. (2012) 157:1173-6. doi: 10.1007/s00705-012-1291-1

37. Li L, Victoria JG, Wang C, Jones M, Fellers GM, Kunz TH, et al. Bat guano virome: predominance of dietary viruses from insects and plants plus novel mammalian viruses . J Virol. (2010) 84:6955-65. doi: 10.1128/JVI.00501-10

38. Wu Z, Ren X, Yang L, Hu Y, Yang J, He G, et al. Virome analysis for identification of novel mammalian viruses in bat species from Chinese provinces. J Virol. (2012) 86:10999-1012. doi: 10.1128/JVI.01394-12

39. Lima FES, Cibulski SP, Dall Bello AG, Mayer FQ, Witt AA, Roehe PM, et al. A novel chiropteran circovirus genome recovered from a Brazilian insectivorous bat species. Microbiol Resour Announc. (2015) 3:e01393-15. doi: 10.1128/genomeA.01393-15

40. Li L, Kapoor A, Slikas B, Bamidele OS, Wang C, Shaukat S, et al. Multiple diverse circoviruses infect farm animals and are commonly found in human and chimpanzee feces. J Virol. (2010) 84:1674-82. doi: 10.1128/JVI.02109-09

41. Li L, McGraw S, Zhu K, Leutenegger CM, Marks SL, Kubiski S, et al. Circovirus in tissues of dogs with vasculitis and hemorrhage. Emerg Infect Dis. (2013) 19:534-41. doi: 10.3201/eid1904.121390

42. Lian H, Liu Y, Li N, Wang Y, Zhang S, Hu R. Novel Circovirus from Mink, et al. Emerg Infect Dis. (2014) 20:1548-50. doi: 10.3201/eid2009.140015 
43. Tischer I, Gelderblom H, Vettermann W, Koch MA. A very small porcine virus with circular single-stranded DNA. Nature (1982) 295:64-66.

44. Crowther RA, Berriman JA, Curran WL, Allan GM, Todd D. Comparison of the Structures of Three Circoviruses: chicken anemia virus, porcine circovirus type 2, and beak and feather disease virus. J Virol (2003) 77:13036-41. doi: 10.1128/JVI.77.24.13036-13041.2003

45. Fenaux M, Halbur PG, Haqshenas G, Royer R, Thomas P, Nawagitgul P, et al. Cloned genomic DNA of type 2 porcine circovirus is infectious when injected directly into the liver and lymph nodes of pigs: characterization of clinical disease, virus distribution, and pathologic lesions. J Virol. (2002) 76:541-51. doi: 10.1128/JVI.76.2.541-551.2002

46. Fenaux M, Halbur PG, Gill M, Toth TE, Meng X-J. Genetic characterization of Type 2 Porcine Circovirus (PCV-2) from pigs with postweaning multisystemic wasting syndrome in different geographic regions of north America and development of a differential PCR-restriction fragment length polymorphism assay. J Clin Microbiol. (2000) 38:2494-503.

47. Meehan BM, Creelan JL, McNulty MS, Todd D. Sequence of porcine circovirus DNA: affinities with plant circoviruses. J Gen Virol. (1997) 78:221-7.

48. Fux R, Söckler C, Link EK, Renken C, Krejci R, Sutter G, et al. Full genome characterization of porcine circovirus type 3 isolates reveals the existence of two distinct groups of virus strains. Virol J. (2018) 15:25. doi: 10.1186/s12985-018-0929-3

49. Zhang D, He K, Wen L, Fan H. Genetic and phylogenetic analysis of a new porcine circovirus type 2 (PCV2) strain in China. Arch Virol. (2015) 160:3149-51. doi: 10.1007/s00705-015-2615-8

50. Guo L, Lu Y, Wei Y, Huang L, Liu C. Porcine circovirus type 2 (PCV2): genetic variation and newly emerging genotypes in China. Virol J. (2010) 7:273. doi: 10.1186/1743-422X-7-273

51. Tischer I, Peters D, Pociuli S. Occurrence and role of an early antigen and evidence for transforming ability of porcine circovirus. Arch Virol. (1995) 140:1799-816. doi: 10.1007/BF01384343

52. Mankertz A, Persson F, Mankertz J, Blaess G, Buhk HJ. Mapping and characterization of the origin of DNA replication of porcine circovirus. J Virol. (1997) 71:2562-6.

53. He J, Cao J, Zhou N, Jin Y, Wu J, Zhou J. Identification and functional analysis of the novel ORF4 protein encoded by porcine circovirus Type 2. J Virol. (2013) 1420-9. doi: 10.1128/JVI.01443-12

54. Gao Z, Dong Q, Jiang Y, Opriessnig T, Wang J, Quan Y, et al. ORF4protein deficient PCV2 mutants enhance virus-induced apoptosis and show differential expression of mRNAs in vitro. Virus Res. (2014) 183:56-62. doi: 10.1016/j.virusres.2014.01.024

55. Lin C, Gu J, Wang H, Zhou J, Li J, Wang S, et al. Caspase-dependent apoptosis induction via viral protein ORF4 of porcine circovirus 2 binding to mitochondrial adenine nucleotide translocase 3. J Virol. (2018) 92:e00238-18. doi: 10.1128/JVI.00238-18

56. Hamel AL, Lin LL, Nayar GSP. Nucleotide sequence of porcine circovirus associated with postweaning multisystemic wasting syndrome in pigs. J Virol. (1998) 72:5262-7.

57. Mankertz A, Çaliskan R, Hattermann K, Hillenbrand B, Kurzendoerfer P, Mueller B, et al. Molecular biology of Porcine circovirus: analyses of gene expression and viral replication. Vet Microbiol. (2004) 98:81-8. doi: 10.1016/j.vetmic.2003.10.014

58. Rosario K, Duffy S, Breitbart M. A field guide to eukaryotic circular singlestranded DNA viruses: insights gained from metagenomics. Arch Virol. (2012) 157:1851-71. doi: 10.1007/s00705-012-1391-y

59. Huang LP, Lu YH, Wei YW, Guo LJ, Liu CM. Identification of one critical amino acid that determines a conformational neutralizing epitope in the capsid protein of porcine circovirus type 2. BMC Microbiol. (2011) 11:188. doi: 10.1186/1471-2180-11-188

60. Lefebvre DJ, Van Doorsselaere J, Delputte PL, Nauwynck HJ. Recombination of two porcine circovirus type 2 strains. Arch Virol. (2009) 154:875-9. doi: 10.1007/s00705-009-0379-8

61. Grierson SS, King DP, Wellenberg GJ, Banks M. Genome sequence analysis of 10 Dutch porcine circovirus type 2 (PCV-2) isolates from a PMWS casecontrol study. Res Vet Sci. (2004) 77:265-268. doi: 10.1016/j.rvsc.2004.04.008

62. Knell S, Willems H, Hertrampf B, Reiner G. Comparative genetic characterization of Porcine Circovirus type 2 samples from
German wild boar populations. Vet Microbiol. (2005) 109:169-77. doi: 10.1016/j.vetmic.2005.06.004

63. Nawagitgul P, Harms PA, Morozov I, Thacker BJ, Sorden SD, Lekcharoensuk $\mathrm{C}$, et al. Modified Indirect Porcine Circovirus (PCV) Type 2-based and recombinant capsid protein (ORF2)-based enzyme-linked immunosorbent assays for detection of antibodies to PCV. Clin Diagn Lab Immunol. (2002) 9:33-40. doi: 10.1128/CDLI.9.1.33-40.2002

64. Mankertz A, Mankertz J, Wolf K, Buhk HJ. Identification of a protein essential for replication of porcine circovirus. J Gen Virol. (1998) doi: 10.1099/0022-1317-79-2-381

65. Huang Y, Shao M, Xu X, Zhang X, Du Q, Zhao X. Evidence for different patterns of natural inter-genotype recombination between two PCV2 parental strains in the field. Virus Res. (2013) 175:78-86. doi: 10.1016/j.virusres.2013.03.014

66. Liu J, Chen I, Kwang J. Characterization of a previously unidentified viral protein in porcine circovirus type 2-infected cells and its role in virus-induced apoptosis. J Virol. (2005) 79:8262-74. doi: 10.1128/JVI.79.13.8262-8274.2005

67. Karuppannan AK, Kwang J. ORF3 of porcine circovirus 2 enhances the in vitro and in vivo spread of the of the virus. Virology (2011) 410:248-56. doi: 10.1016/j.virol.2010.11.009

68. Lin WL, Chien MS, Wu P-C, Lai CL, Huang C. The porcine circovirus type 2 nonstructural protein ORF3 induces apoptosis in porcine peripheral blood mononuclear cells. Open Virol J. (2011) 5:148-53. doi: 10.2174/1874357901105010148

69. Zou Y, Zhang N, Zhang J, Zhang S, Jiang Y, Wang D, et al. Molecular detection and sequence analysis of porcine circovirus type 3 in sow sera from farms with prolonged histories of reproductive problems in Hunan, China. Arch Virol. (2018) 163:2841-47. doi: 10.1007/s00705-0183914-7

70. Ku X, Chen F, Li P, Wang Y, Yu X, Fan S, et al. Identification and genetic characterization of porcine circovirus type 3 in China. Transbound Emerg Dis. (2017) 64:703-8. doi: 10.1111/tbed.12638

71. Zheng S, Wu X, Zhang L, Xin C, Liu Y, Shi J, et al. The occurrence of porcine circovirus 3 without clinical infection signs in Shandong Province. Transbound Emerg Dis. (2017) 64:1337-41. doi: 10.1111/tbed.12667

72. Li X, Bai Y, Zhang H, Zheng D, Wang T, Wang Y, et al. Production of a monoclonal antibody against Porcine circovirus type 3 cap protein. J Virol Methods (2018) 261:10-13. doi: 10.1016/j.jviromet.2018.07.014

73. Fu X, Fang B, Ma J, Liu Y, Bu D, Zhou P, et al. Insights into the epidemic characteristics and evolutionary history of the novel porcine circovirus type 3 in southern China. Transbound Emerg Dis. (2017) 65:e296-303. doi: $10.1111 /$ tbed. 12752

74. Li G, He W, Zhu H, Bi Y, Wang R, Xing G, et al. Origin, genetic diversity, and evolutionary dynamics of novel porcine circovirus 3. Adv Sci. (2018) 5:1800275. doi: 10.1002/advs.201800275

75. Faccini S, Barbieri I, Gilioli A, Sala G, Gibelli LR, Moreno A, et al. Detection and genetic characterization of Porcine circovirus type 3 in Italy. Transbound Emerg Dis. (2017) 64:1661-4. doi: 10.1111/tbed.12714

76. Franzo G, Legnardi M, Hjulsager C. K, Klaumann F, Larsen L. E, Segales J, et al. Full-genome sequencing of porcine circovirus 3 field strains from Denmark, Italy and Spain demonstrates a high withinEurope genetic heterogeneity. Transbound Emerg Dis. (2018) 65:602-6. doi: $10.1111 /$ tbed.12836

77. Stadejek T, Wozniak A, Miłek D, Biernacka K. First detection of porcine circovirus type 3 on commercial pig farms in Poland. Transbound Emerg Dis. (2017) 64:1350-3. doi: 10.1111/tbed.12672

78. Sun J, Wei L, Lu Z, Mi S, Bao F, Guo H, et al. Retrospective study of porcine circovirus 3 infection in China. Transbound Emerg Dis. (2018) 65:607-13. doi: $10.1111 /$ tbed.12853

79. Tochetto C, Lima DA, Varela APM, Loiko MR, Paim WP, Scheffer CM, et al. Full-Genome Sequence of Porcine Circovirus type 3 recovered from serum of sows with stillbirths in Brazil. Transbound Emerg Dis. (2017) 65:5-9. doi: 10.1111/tbed.12735

80. Yuzhakov AG, Raev SA, Alekseev KP, Grebennikova TV, Verkhovsky $\mathrm{OA}$, Zaberezhny $\mathrm{AD}$, et al. First detection and full genome sequence of porcine circovirus type 3 in Russia. Virus Genes (2018) 54:608-11. doi: $10.1007 / \mathrm{s} 11262-018-1582-\mathrm{z}$ 
81. Klaumann F, Franzo G, Sohrmann M, Florencia C-F, Drigo M, Núñez JI, et al. Retrospective detection of Porcine circovirus 3 (PCV-3) in pig serum samples from Spain. Transbound Emerg Dis. (2018) 65:1290-96. doi: $10.1111 /$ tbed.12876

82. Kwon T, Yoo SJ, Park CK, Lyoo YS. Prevalence of novel porcine circovirus 3 in Korean pig populations. Vet Microbiol. (2017) 207:178-80. doi: 10.1016/j.vetmic.2017.06.013

83. Klaumann F, Franzo G, Drigo M, Sibila M, Correa-Fiz F, Núñez JI, et al. Infection dynamics of Porcine circovirus 3 in longitudinally sampled pigs from a Spanish farm. 10th Eur Symp Porc Health Manag. (2018) VVD-030.

84. Kedkovid R, Woonwong Y, Arunorat J, Sirisereewan C, Sangpratum $\mathrm{N}$, Kesdangsakonwut $\mathrm{S}$, et al. Porcine circovirus type 3 (PCV3) shedding in sow colostrum. Vet Microbiol. (2018) 220:12-17. doi: 10.1016/j.vetmic.2018.04.032

85. Collins PJ, McKillen J, Allan G. Porcine circovirus type 3 in the UK. Vet Rec. (2017) 181:599. doi: 10.1136/vr.j5505

86. Xu PL, Zhang Y, Zhao Y, Zheng HH, Han HY, Zhang HX, et al. Detection and phylogenetic analysis of porcine circovirus type 3 in central China. Transbound Emerg Dis. (2018) 65:1163-69. doi: 10.1111/tbed.12920

87. Zhai S-L, Zhou X, Zhang H, Hause BM, Lin T, Liu R, et al. Comparative epidemiology of porcine circovirus type 3 in pigs with different clinical presentations. Virol J. (2017) 14:222. doi: 10.1186/s12985-017-0892-4

88. Wen S, Sun W, Li Z, Zhuang X, Zhao G, Xie C, et al. The detection of porcine circovirus 3 in Guangxi, China. Transbound Emerg Dis. (2017) 65:27-31. doi: $10.1111 /$ tbed.12754

89. Franzo G, Legnardi M, Centelleghe C, Tucciarone CM, Cecchinato M, Cortey $M$, et al. Development and validation of direct PCR and quantitative PCR assays for the rapid, sensitive, and economical detection of porcine circovirus 3. J Vet Diagnostic Invest. (2018) 1040638718770495. doi: 10.1177/1040638718770495

90. Hayashi S, Ohshima Y, Furuya Y, Nagao A, Oroku K, Tsutsumi N, et al. First detection of porcine circovirus type 3 in Japan. J Vet Med Sci. (2018) 80:1468-72. doi: 10.1292/jvms.18-0079

91. Kedkovid R, Woonwong Y, Arunorat J, Sirisereewan C, Sangpratum N, Lumyai $\mathrm{M}$, et al. Porcine circovirus type 3 (PCV3) infection in grower pigs from a Thai farm suffering from porcine respiratory disease complex (PRDC). Vet Microbiol. (2018) 215:71-6. doi: 10.1016/j.vetmic.2018.01.004

92. Zhao D, Wang X, Gao Q, Huan C, Wang W, Gao S, et al. Retrospective survey and phylogenetic analysis of porcine circovirus type 3 in Jiangsu province, China, 2008 to 2017. Arch Virol. (2018) 163:2531-38. doi: 10.1007/s00705-018-3870-2

93. Ye X, Berg M, Fossum C, Wallgren P, Blomström A-L. Detection and genetic characterisation of porcine circovirus 3 from pigs in Sweden. Virus Genes (2018) 54:466-9. doi: 10.1007/s11262-018-1553-4

94. Kim SC, Nazki S, Kwon S, Juhng JH, Mun KH, Jeon DY, et al. The prevalence and genetic characteristics of porcine circovirus type 2 and 3 in Korea. BMC Vet Res. (2018) 14:294. doi: 10.1186/s12917-018-1614-x

95. Klaumann F, Dias-Alves A, Cabezón O, Mentaberre G, Castillo-Contreras R, López-Béjar $\mathrm{M}$, et al. Porcine circovirus 3 is highly prevalent in serum and tissues and may persistently infect wild boar (Sus scrofa scrofa). Transbound Emerg Dis. (2018) doi: 10.1111/tbed.12988. [Epub ahead of print].

96. Franzo G, Tucciarone CM, Drigo M, Cecchinato M, Martini M, Mondin A, et al. First report of wild boar susceptibility to Porcine circovirus type 3: high prevalence in the Colli Euganei Regional Park (Italy) in the absence of clinical signs. Transbound Emerg Dis. (2018) 65:957-62. doi: 10.1111/tbed.12905

97. Zhang J, Liu Z, Zou Y, Zhang N, Wang D, Tu D, et al. First molecular detection of porcine circovirus type 3 in dogs in China. Virus Genes (2017) 54(1):140-44. doi: 10.1007/s11262-017-1509-0

98. Franzo G, Legnardi M, Tucciarone CM, Drigo M, Klaumann F, Sohrmann M, et al. Porcine circovirus type 3: a threat to the pig industry? Vet Rec. (2018) 182:83 LP-83. doi: 10.1136/vr.k91

99. Shen H, Liu X, Zhang P, Wang L, Liu Y, Zhang L, et al. Genome characterization of a porcine circovirus type 3 in South China. Transbound Emerg Dis. (2017) 65:264-6. doi: 10.1111/tbed. 12639

100. Franzo G, Kekarainen T, Llorens A, Correa-Fiz F, Segalés J. Exploratory metagenomic analyses of periweaning failure-to-thrive syndrome (PFTS) affected pigs. Vet Rec. (2018) doi: 10.1136/vr.105125. [Epub ahead of print].
101. Chen GH, Mai KJ, Zhou L, Wu RT, Tang XY, Wu JL, et al. Detection and genome sequencing of porcine circovirus 3 in neonatal pigs with congenital tremors in South China. Transbound Emerg Dis. (2017) 64:1650-4. doi: $10.1111 /$ tbed.12702

102. Olvera A, Sibila M, Calsamiglia M, Segalés J, Domingo M. Comparison of porcine circovirus type 2 load in serum quantified by a real time PCR in postweaning multisystemic wasting syndrome and porcine dermatitis and nephropathy syndrome naturally affected pigs. J Virol Methods (2004) 117:75-80. doi: 10.1016/j.jviromet.2003. 12.007

103. Brunborg IM, Jonassen CM, Moldal T, Bratberg B, Lium B, Koenen $\mathrm{F}$, et al. Association of myocarditis with high viral load of porcine circovirus type 2 in several tissues in cases of fetal death and high mortality in piglets. A case study. J Vet Diagn Invest. (2007) 19:368-75. doi: 10.1177/104063870701900405

104. Kim HR, Park YR, Lim DR, Park MJ, Park JY, Kim SH, et al. Multiplex real-time polymerase chain reaction for the differential detection of porcine circovirus 2 and 3. J Virol Methods (2017) 250:11-6. doi: 10.1016/j.jviromet.2017.09.021

105. Li X, Qiao M, Sun M, Tian K. A Duplex Real-Time PCR Assay for the simultaneous detection of porcine circovirus 2 and circovirus 3. Virol Sin. (2018) 33:181-6. doi: 10.1007/s12250-018-0025-2

106. Deng J, Li X, Zheng D, Wang Y, Chen L, Song H, et al. Establishment and application of an indirect ELISA for porcine circovirus 3. Arch Virol. (2018) 163:479-82. doi: 10.1007/s00705-017-3607-7

107. Shulman LM, Davidson I. Viruses with circular single-stranded DNA genomes are everywhere! Annu Rev Virol. (2017) 4:159-80. doi: 10.1146/annurev-virology-101416-041953

108. Lohse L, Bøtner A, Hansen A-SL, Frederiksen T, Dupont K, Christensen CS, et al. Examination for a viral co-factor in postweaning multisystemic wasting syndrome (PMWS). Vet Microbiol. (2008) 129:97-07. doi: 10.1016/j.vetmic.2007.11.018

109. Shi M, Lemey P, Singh Brar M, Suchard MA, Murtaugh MP, Carman S, et al. The spread of Type 2 Porcine Reproductive and Respiratory Syndrome Virus (PRRSV) in North America: a phylogeographic approach. Virology (2013) 447:146-54. doi: 10.1016/j.virol.2013.08.028

110. Franzo G, Tucciarone CM, Dotto G, Gigli A, Ceglie L, Drigo M. International trades, local spread and viral evolution: the case of porcine circovirus type 2 (PCV2) strains heterogeneity in Italy. Infect Genet Evol. (2015) 32:409-15. doi: 10.1016/j.meegid.2015.04.004

111. Madec F, Rose N, Grasland B, Cariolet R, Jestin A. Post-weaning multisystemic wasting syndrome and other PCV2-related problems in pigs: a 12-Year experience. Transbound Emerg Dis. (2008) 55:273-83. doi: 10.1111/j.1865-1682.2008.01035.x

112. Grau-Roma L, Fraile L, Segalés J. Recent advances in the epidemiology, diagnosis and control of diseases caused by porcine circovirus type 2 . Vet J. (2011) 187:23-32. doi: 10.1016/j.tvjl.2010.01.018

113. Dekkers J, Rowland RRR, Lunney JK, Plastow G. Host genetics of response to porcine reproductive and respiratory syndrome in nursery pigs. Vet Microbiol. (2017) 209:107-13. doi: 10.1016/j.vetmic.2017. 03.026

114. Zheng S, Shi J, Wu X, Peng Z, Xin C, Zhang L, et al. Presence of Torque teno sus virus 1 and 2 in porcine circovirus 3-positive pigs. Transbound Emerg Dis. (2018) 65:327-30. doi: 10.1111/tbed.12792

115. Allan GM, Kennedy S, McNeilly F, Foster JC, Ellis JA, Krakowka SJ, et al. Experimental reproduction of severe wasting disease by co-infection of pigs with porcine circovirus and porcine parvovirus. J Comp Pathol. (1999) 121:1-11. doi: 10.1053/jcpa.1998.0295

116. Allan GM, Ellis JA. Porcine Circoviruses: a review. J Vet Diagnostic Invest. (2000) 12:3-14. doi: 10.1177/104063870001200102

117. Larochelle R, Magar R, D'Allaire S. Comparative serologic and virologic study of commercial swine herds with and without postweaning multisystemic wasting syndrome. Can J Vet Res. (2003) 67:114-20.

118. Sibila M, Calsamiglia M, Segales J, Blanchard P, Badiella L, Dimna M. Use of a polymerase chain reaction assay and an ELISA to monitor porcine circovirus type 2 infection in pigs from farms with and without postweaning multisystemic wasting syndrome. Am J Vet Res. (2004) 65:8892. doi: 10.2460/ajvr.2004.65.88 
119. Rodriguez-Arrioja GM, Segales J, Calsamiglia M, Resendes AR, Balasch M, Plana-Duran J. Dynamics of porcine circovirus type 2 infection in a herd of pigs with postweaning multisystemic wasting syndrome. Am J Vet Res. (2002) 63:354-7. doi: 10.2460/ajvr.2002.63.354

120. Rodríguez-Arrioja GM, Segalés J, Rosell C, Rovira A, Pujols J, PlanaDurán J, et al. Retrospective study on porcine circovirus type 2 infection in pigs from 1985 to 1997 in Spain. J Vet Med Ser B (2003) 50:99-101. doi: 10.1046/j.1439-0450.2003.00621.x

121. Grau-Roma L, Hjulsager CK, Sibila M, Kristensen CS, López-Soria S, Enøe C. Infection, excretion and seroconversion dynamics of porcine circovirus type 2 (PCV2) in pigs from post-weaning multisystemic wasting syndrome (PMWS) affected farms in Spain and Denmark. Vet Microbiol. (2009) 135:272-82. doi: 10.1016/j.vetmic.2008.10.007

122. McIntosh KA, Harding JCS, Ellis JA, Appleyard GD. Detection of Porcine circovirus type 2 viremia and seroconversion in naturally infected pigs in a farrow-to-finish barn. Can J Vet Res. (2006) 70:58-61.

123. Meng XJ, Lindsay DS, Sriranganathan N. Wild boars as sources for infectious diseases in livestock and humans. Philos Trans R Soc B Biol Sci. (2009) 364:2697-07. doi: 10.1098/rstb.2009.0086

124. Lipej Z, Segalés J, Jemeršić L, Olvera A, Roić B, Novosel D, et al. First description of postweaning multisystemic wasting syndrome (PMWS) in wild boar ( Sus scrofa ) in Croatia and phylogenetic analysis of partial PCV2 sequences. Acta Vet Hung. (2007) 55:389-404. doi: 10.1556/AVet.55.2007.3.13

125. Gilliland SM, Forrest L, Carre H, Jenkins A, Berry N, Martin J, et al. Investigation of porcine circovirus contamination in human vaccines. Biologicals (2012) 40:270-7. doi: 10.1016/j.biologicals.2012.02.002

126. Denner J, Mankertz A. Porcine Circoviruses and Xenotransplantation. Viruses (2017) 9:83. doi: 10.3390/v9040083

127. Jacobsen B, Krueger L, Seeliger F, Bruegmann M, Segalés J, Baumgaertner W. Retrospective study on the occurrence of porcine circovirus 2 infection and associated entities in Northern Germany. Vet Microbiol. (2009) 138:27-33. doi: 10.1016/j.vetmic.2009.02.005

128. da Silva FMF, Júnior AS, de Oliveira Peternelli EF, Viana VW, Neto OC, Fietto JLR, et al. Retrospective study on Porcine circovirus-2 by nested pcr and real time pcr in archived tissues from 1978 in brazil. Brazilian J Microbiol. (2011) 42:1156-60. doi: 10.1590/S1517-8382201100030 00039

129. Ramírez-Mendoza H, Castillo-Juárez H, Hernández J, Correa P, Segalés J. Retrospective serological survey of Porcine circovirus-2 infection in Mexico. Can J Vet Res. (2009) 73:21-24.

130. Saraiva GL, Vidigal PMP, Fietto JLR, Bressan GC, Silva Júnior A, de Almeida MR. Evolutionary analysis of Porcine circovirus 3 (PCV3) indicates an ancient origin for its current strains and a worldwide dispersion. Virus Genes (2018) 54:376-84. doi: 10.1007/s11262-018-1545-4

131. Li G, Wang H, Wang S, Xing G, Zhang C, Zhang W, et al. Insights into the genetic and host adaptability of emerging porcine circovirus 3. Virulence (2018) 9:1301-13. doi: 10.1080/21505594.2018. 1492863

132. Franzo G, Segales J, Tucciarone CM, Cecchinato M, Drigo M. The analysis of genome composition and codon bias reveals distinctive patterns between avian and mammalian circoviruses which suggest a potential recombinant origin for Porcine circovirus 3. PLoS ONE (2018) 13:e0199950. doi: 10.1371/journal.pone.0199950

133. Nishizawa T, Sugimoto Y, Takeda T, Kodera Y, Hatano Y, Takahashi M, et al. Identification and full-genome characterization of novel circoviruses in masked palm civets (Paguma larvata). Virus Res. (2018) 258:50-4. doi: 10.1016/j.virusres.2018.10.004

Conflict of Interest Statement: The authors declare that the research was conducted in the absence of any commercial or financial relationships that could be construed as a potential conflict of interest.

Copyright (c) 2018 Klaumann, Correa-Fiz, Franzo, Sibila, Núñez and Segalés. This is an open-access article distributed under the terms of the Creative Commons Attribution License (CC BY). The use, distribution or reproduction in other forums is permitted, provided the original author(s) and the copyright owner(s) are credited and that the original publication in this journal is cited, in accordance with accepted academic practice. No use, distribution or reproduction is permitted which does not comply with these terms. 